\title{
PENGARUH MODEL PEMBELAJARAN KOOPERATIF TIPE NUMBERED HEAD TOGETHER) DENGAN MEDIA KOTAK MATRIKS TERHADAP KEMAMPUAN PEMAHAMAN KONSEP MATEMATIKA SISWA KELAS XI IPA SMA NEGERI 1 SELESAI
}

\author{
Kurnia Agustina $^{1)}$, Silvia Harleni ${ }^{2)}$, Sanimah ${ }^{3)}$ \\ Mahasiswa STKIP Budidaya Binjai Prodi Pendidikan Matematika

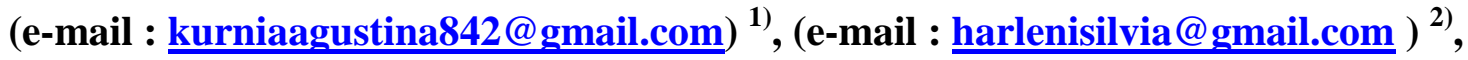 \\ (e-mail : sanimah220989@ gmail.com) ${ }^{3)}$
}

\begin{abstract}
ABSTRAK
Tujuan penelitian ini untuk mengetahui pengaruh model pembelajaran kooperatif tipe NHT (Numbered Heads Together) dengan media kotak matriks terhadap kemampuan pemahaman konsep matematika siswa. Penelitian ini dilakukan di SMA Negeri 1 Selesai Tahun Pelajaran 2019/2020. Jenis penelitian yang digunakan dalam penelitian ini adalah eksperimen semu (quasi experimental). Desain penelitian ini adalah Pretest-Posttest Control Group Design. Sampel yang digunakan dalam penelitian ini adalah kelas XI IPA 3 yang berjumlah 32 siswa sebagai kelas eksperimen dan kelas XI IPA 4 yang berjumlah 30 siswa sebagai kelas kontol. Teknik sampling yang digunakan adalah Simple Random Sampling. Instrumen yang digunakan dalam penelitian ini berupa tes kemampuan pemahaman konsep matematika siswa berbentuk uraian sebanyak 4 soal. Uji prasyarat yang digunakan adalah uji Liliefors untuk menguji normalitas data, sedangkan uji fisher untuk menguji homogenitas data. Berdasarkan hasil uji normalitas diperoleh bahwa kedua populasi berdistribusi normal. Sedangkan hasil uji homogenitas diperoleh bahwa kedua populasi homogen (sama). Berdasarkan hasil penelitian mengungkapkan bahwa model pembelajaran kooperatif tipe NHT (Numbered Head Together) dengan media kotak matriks sangat berpengaruh terhadap kemampuan pemahaman konsep matematika siswa. Hal ini dapat dilihat dari nilai ratarata kelas eksperimen adalah sebesar 73,63 dan nilai rata-rata kelas kontrol adalah sebesar 50,23. Terdapat pengaruh yang signifikan antara pembelajaran kooperatif tipe NHT terhadap pemahaman konsep matematika siswa yang dapat dilihat dari hasil perhitungan analisis data yang menggunakan uji-t dengan nilai $t_{\text {hitung }}>t_{\text {tabel }}$ $(4,499>1,671)$ dengan derajat kebebasan $(\mathrm{db})=60$, dengan taraf signifikan 0,05. Dengan demikian $\mathrm{H}_{\mathrm{o}}$ ditolak dan $\mathrm{H}_{\mathrm{a}}$ diterima, yang artinya rata-rata pemahaman konsep matematika siswa pada kelas eksperimen lebih besar dari rata-rata pemahaman konsep matematika siswa pada kelas kontrol. Hal ini berarti terdapat pengaruh penggunaan model pembelajaran kooperatif tipe NHT ( Numbered Head Together) dengan media kotak matriks terhadap kemampuan pemahaman konsep matematika siswa di kelas XI IPA SMA Negeri 1 Selesai.
\end{abstract}

Kata Kunci : Model Pembelajaran Kooperatif; NHT; Media Kotak Matriks; Kemampuan Pemahaman Konsep Matematika.

\section{PENDAhuluan}

Pendidikan adalah segala pengalaman belajar yang mempengaruhi pertumbuhan individu dalam segala lingkungan yang berlangsung sepanjang hidup. Di dalam pendidikan terdapat sebuah teori, dimana sebuah teori adalah sebuah sistem konsep-konsep yang terpadu, menerangkan dan memprediksi. Hal senada diungkapkan oleh Mudyahardjo, yang menegaskan bahwa "Sebuah teori berisi konsep-konsep, ada yang berfungsi sebagai: (1) asumsi atau konsep-konsep, yang menjadi dasar atau titik tolak pemikiran sebuah teori; dan (2) definisi konotatif atau denotatif atau konsep-konsep yang menyatakan makna dari istilah-istilah yang dipergunakan dalam menyusun teori" (Mudyahardjo, 2001:91).

Tujuan pendidikan yaitu untuk meningkatkan kualitas sumber daya manusia, karena sumber daya manusia yang berkualitas 
akan menjadi tumpuan utama agar suatu bangsa dapat berkompetisi. Salah satu upaya yang dapat dilakukan adalah dengan meningkatkan kualitas pendidikan, misalnya pemerintah telah melakukan berbagai upaya dalam meningkatkan kualitas pendidikan seperti perubahan kurikulum, penataran guru pada setiap jenjang pendidikan, penyediaan sarana dan prasarana. Hamid (dalam Harleni, 2018) menyatakan bahwa peningkatan kualitas pendidikan menunjukkan pada upaya peningkatan kualitas proses dan hasil pembelajaran. Namun kenyataannya, pendidikan di indonesia masih sangatlah memprihatinkan. Terlihat dari turunnya kualitas dan semangat belajar anak didik.

Sesuai dengan pendapat Kunandar yang menyatakan bahwa "Sejauh ini pendidikan masih didominasi oleh pandangan bahwa pengetahuan sebagai perangkat faktafakta yang harus dihapal. Kelas masih berfokus pada guru sebagai sumber utama pengetahuan, kemudian ceramah menjadi pilihan utama strategi belajar" Kunandar, 2007:294). Masalah belajar memiliki peranan penting dalam menentukan prestasi peserta didik. Namun belajar masih sering didefenisikan sebagai rutinitas atau pun tuntutan sekolah. Seperti yang diungkapkan (Slameto, 2011:1): Belajar merupakan suatu kegiatan menghafal sejumlah fakta-fakta. Seorang yang telah belajar akan ditandai dengan banyaknya fakta-fakta yang dapat dihafalkannya . guru yang berpendapat demikian tentu akan merasa puas ketika siswanya mampu menghafalkan sejumlah fakta diluar kepala. Pendapat lain menyatakan bahwa belajar merupakan suatu latihan sehingga hasilhasil belajar akan tampak dalam keterampilanketerampilan tertentu sebagai hasil latihan. Sehingga ketika seseorang ingin mahir dalam matematika maka ia harus berlatih mengerjakan soal-soal matematika.

Untuk itu diperlukan sebuah strategi belajar yang baru yang lebih memberdaya peserta didik. Seperti yang di ungkapkan oleh Istarani dalam bukunya, strategi pembelajaran adalah suatu kegiatan pembelajaran yang harus dikerjakan guru dan siswa agar tujuan pembelajaran dapat dicapai secara efektif dan efisien. Dan beliau juga mengungkapkan bahwa metode digunakan untuk merealisasikan strategi yang telah ditetapkan (Istarini, 2011:1). Matematika merupakan suatu ilmu yang berhubungan atau menelaah bentuk-bentuk atau struktur-struktur yang abstrak dan hubungan-hubungan diantara hal-hal itu. Hujodo (dalam Harleni, 2019) menyatakan bahwa matematika adalah suatu alat mengembangkan cara berfikir. Karena itu matematika diperlukan untuk kehidupan sehari-hari maupun dalam menghadapi kemajuan IPTEK sehingga matematika perlu dibekalkan kepada setiap peserta didik sejak SD, bahkan sejak TK.Untuk dapat memahami struktur-struktur serta hubungan-hubungan, tentu saja diperlukan pemahaman tentang konsep-konsep yang terdapat di dalam matematika itu, sejalan dengan hal tersebut, menurut Depdiknas No 22 Tahun 2006 salah satu tujuan matematika pada pendidikan di sekolah adalah agar peserta didik memiliki kemampuan memahami konsep matematika, menjelaskan keterkaitan konsep dan mengaplikasikan konsep dan algoritma secara luwes, akurat, efisien dan tepat dalam memecahkan masalah.

Berdasarkan tujuan tersebut tampak bahwa siswa dituntut untuk memiliki kemampuan pemahaman konsep matematika yang baik. Hal ini juga diungkapkan oleh NCTM (National Council Of Mathematics) yang menyatakan bahwa: "siswa harus belajar matematika dengan pemahaman, dan secara aktif membangun pengetahuan baru dari pengalaman dan pengetahuan sebelumnya ". Maka jelaslah bahwa dalam proses pembelajaran matematika, pemahaman konsep merupakan landasan yang sangat penting untuk berpikir dalam menyelesaikan masalah matematika maupun permasalahan sehari-hari. (Zulkardi, 2010) menyatakan bahwa "pelajaran matematika menekankan pada pemahaman konsep", artinya dalam mempelajari matematika, siswa harus memahami konsep matematika terlebih dahulu agar dapat menyelesaikan soal-soal dan mampu mengaplikasikan pembelajaran tersebut dalam dunia nyata. Senada dengan itu, (Herawati Oktiana D. P. 2010) menyatakan apabila 
pemahaman konsep dalam pembelajaran matematika tidak tercapai, maka akan mengurangi minat peserta didik dalam pembelajaran matematika itu sendiri dan peserta didik akan menganggap matematika itu susah.

Dan kenyataan yang terjadi di lapangan menunjukan bahwa pemahaman konsep matematika siswa diindonesia masih sangat rendah. Hal ini ditunjukan oleh hasil survai TIMSS tahun 2011 dengan rata-rata persentase jawaban benar siswa indonesia pada survai TIMSS tahun 2011 adalah $31 \%$ knowing, 23\% applying, dan $17 \%$ reasoning. Rata-rata tersebut jauh di bawah rata-rata persentase jawaban benar internasional, yaitu: $49 \%$ knowing, 39\% applying, dan $30 \%$ reasoning (Muhlis, 2011). Rendahnya kemampuan pemahaman konsep matematika karena siswa memandang pembelajaran matematika sangat sulit dipahami, membosankan, menakutkan, bahkan jenuh dengan guru yang membawakan mata pembelajaran matematika.

Banyak hal yang harus dipelajari dalam pelajaran matematika, kurangnya minat dan kemampuan dalam memahami konsep matematika sangat berpengaruh dalam pembelajaran matematika. Kemampuan siswa yang rendah dalam aspek penguasaan konsep merupakan hal penting yang harus ditindak lanjuti. Menurut (Sagala, 2013:71) : Konsep merupakan buah pemikiran seseorang atau sekelompok orang yang dinyatakan dalam defenisi sehingga melahirkan produk pengetahuan meliputi prinsip, hukum, dan teori. Konsep diperoleh dari fakta, peristiwa, pengalaman, melalui generalisasi dan berfikir abstrak, kegunaan konsep untuk menjelaskan dan meramalkan. Konsep dapat mengalami perubahan disesuaikan dengan fakta atau pengetahuan baru, sedangkan kegunaan konsep adalah menjelaskan dan meramalkan. Penelitian tentang pemahaman konsep telah banyak dilakukan, salah satunya Harleni dan Ningtias (2019) yang meneliti tentang pengaruh model pembelajaran Konstektual terhadap pemahaman konsep matematis siswa.

Berdasarkan observasi awal yang dilakukan oleh peneliti, bahwa banyak siswa yang kurang mampu memahami pelajaran matematika terutama memahami konsep pelajaran matematika itu sendiri. Pada perangkat pembelajaran dituliskan guru akan melaksanakan pembelajaran menggunakan model PBL akan tetapi pelaksanaan di kelas, guru belum menerapkan model PBL secara maksimal. Guru masih melaksanakan pembelajaran dengan cara konvensional, dimana guru lebih aktif dari pada siswa. Siswa lebih cenderung melihat jawaban siswa yang lebih pandai dari pada harus mengerjakan sendiri soal-soal yang diberikan. Selain itu, partisipasi dan pemahaman konsep siswa pada saat mengikuti pelajaran matematika kurang terlihat dalam pengerjaan latihan yang diberikan oleh guru karena hanya beberapa siswa yang mengerjakannya. Permasalahan tersebut terbukti pada saat peneliti melakukan penelitian awal di kelas XI IPA 3 SMA Negeri 1 Selesai. Dengan memberikan tes pemahaman konsep yang berbentuk soal essay sebanyak 4 soal. Salah satu tes yang diberikan sebagai berikut:

Tentukan matriks Q dari operasi matriks berikut:

$$
\left[\begin{array}{cc}
8 & 18 \\
-1 & 8
\end{array}\right]-Q=\left[\begin{array}{cc}
12 & -8 \\
-6 & -20
\end{array}\right]
$$

Gambar 1. Tes Yang Diberikan Kepada Siswa

Jawaban siswa:

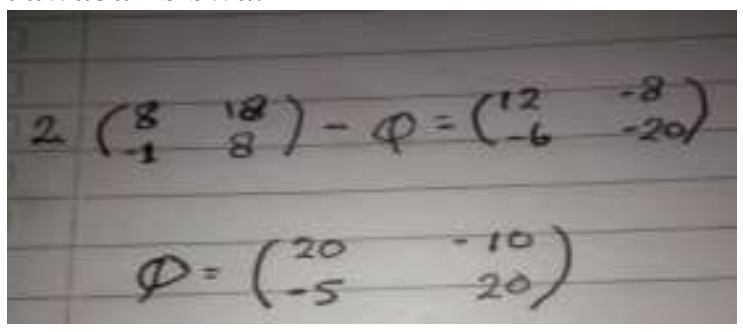

Gambar 2 Jawaban Siswa

Dari hasil jawaban salah satu siswa di atas menunjukan bahwa siswa mengalami kesulitan saat menentukan nilai matriks Q, siswa tidak memahami konsep dasar pengurangan matriks. Kurangnya pemahaman konsep siswa terhadap soal yang diberikan dapat dilihat dari tidak ditulisnya langkahlangkah penyelesaian untuk mendapatkan 
jawaban dengan benar, siswa tersebut hanya langsung menjawab nilai dari matriks Q, itupun hasilnya masih salah karena siswa menjawab

$$
Q=\left[\begin{array}{cc}
12 & -8 \\
-6 & -20
\end{array}\right] \text {, harusnya } Q=\left[\begin{array}{cc}
-4 & 26 \\
5 & 28
\end{array}\right] \text {. }
$$

Soal tersebut diberikan kepada 32 siswa. Berdasarkan pengamatan peneliti dari hasil observasi, 11 orang diantaranya tidak menjawab soal tersebut, 12 orang menjawab soal dengan salah, dan 9 orang menjawab soal dengan benar. Dari hasil tersebut, peneliti menyimpulkan bahwa kemampuan pemahaman konsep matematika siswa masih rendah. Hal ini dikarenakan siswa tidak mampu menyelesaikan soal dengan tepat sesuai dengan langkahlangkah yang benar, siswa tidak dapat menyatakan ulang suatu konsep, siswa tidak mampu menyajikan situasi keberbagai cara, siswa tidak mampu mengklasifikasi objekobjek, dan menetapkan konsep secara algoritma serta mengembangkan konsep yang telah dipelajari. Rendahnya pemahaman konsep matematika siswa sangat berpengaruh pada hasil belajar siswa.

Kurikulum yang diterapkan di SMA Negeri 1 Selesai ialah kurikulum 2013. Dimana kurikulum ini menuntut siswa untuk lebih aktif lagi dalam belajar dan guru dituntut menggunakan model pembelajaran yang inovatif seperti perpaduan model pembelajaran dengan media. Namun di sekolah SMA Negeri 1 Selesai guru hanya menggunakan model pembelajaran yang pelaksanaannya belum maksimal serta jarang menggunakan media. Salah satu cara menciptakan pembelajaran yang bermakna bagi siswa agar siswa mampu memahami konsep matematika dengan benar yaitu dengan menggunakan model pembelajaran yang inovatif dengan pemilihan media yang sesuai. Dari uraian yang dikemukakan di atas peneliti akan menggunakan model pembelajaran yang inovatif yaitu model pembelajaran kooperatif tipe NHT (Numbered Heads Together) dengan media kotak matriks agar memudahkan siswa dalam memahami konsep matriks khususnya mengenai operasi dasar matriks.
Model pembelajaran tipe NHT (Numbered Head Together) merupakan salah satu dari strategi pembelajaran kooperatif. Model pembelajaran ini dikembangkan oleh Spenser Kagan dalam buku (Shoimin, 2016:107) : model NHT mengacu pada belajar kelompok siswa, masing-masing anggota memiliki bagian tugas (pertanyaan) dengan nomor yang berbeda-beda. Pembelajaran kooperatif tipe NHT (Numbered Head Together) memiliki kelebihan yaitu dapat memungkinkan siswa menjadi lebih aktif dan bertanggung jawab penuh dalam memahami materi pelajaran baik kelompok maupun individu. Dalam penelitian ini, media yang akan digunakan peneliti yaitu kotak matriks. media ini akan dipadukan oleh model pembelajaran NHT (Numbered Head Together).

Seperti penelitian yang pernah dilakukan oleh Eka Rahmawati, Yesi Gusmania, dalam penelitian yang berjudul "Pengaruh Model Pembelajaran Kooperatif Tipe Numbered Head Together (NHT) Terhadap Pemahaman Konsep Matematis Siswa Kelas VIII Smp Negeri 53 Batam" dimana model pembelajaran NHT lebih baik dari pada model pembelajaran konvensional. Suwardi, Masni Erika Firmiana, dan Rohayati juga melakukan penelitian yang berjudul "Pengaruh Penggunaan Alat Peraga terhadap Hasil Pembelajaran Matematika pada Anak Usia Dini” yang menyatakan bahwa terdapat pengaruh yang signifikan penggunaan alat peraga terhadap hasil belajar matematika pada anak usia dini.

Berdasarkan uraian di atas, peneliti tertarik untuk melakukan penelitian dengan judul "Pengaruh Model Pembelajaran Kooperatif Tipe Numbered Head Together Dengan Media Kotak Matriks Terhadap Kemampuan Pemahaman Konsep Matematika Siswa Kelas XI IPA SMA Negeri 1 Selesai”.

\section{METODE PENELITIAN}

Lokasi penelitian ini di SMA Negeri 1 Selesai, Jl. Binjai-Selayang Simpang Selesai, Padang Brahrang. Populasi dalam penelitian ini adalah 
seluruh siswa kelas XI IPA SMA Negeri 1 Selesai yang terdiri dari empat kelas. Dalam penentuan pemilihan sampel ini, teknik sampling yang digunakan adalah Simple Random Sampling. Sampel yang digunakan dalam penelitian ini adalah dua kelas dimana nama yang keluar pertama sebagai kelas eksperimen yaitu kelas XI IPA 3 yang berjumlah 32 siswa. Setelah itu pengundian kedua nama yang keluar sebagai kelas kontrol yaitu kelas XI IPA 4 yang berjumlah 30 siswa. Dengan demikian sampel keseluruhan berjumlah 62 siswa.

Jenis penelitian yang digunakan dalam penelitian ini adalah eksperimen semu (quasi experimental). Perlakuan yang diberikan yaitu pembelajaran matematika dengan menggunakan model pembelajaran kooperatif tipe Numbered Head Together (NHT) pada kelas eksperimen dan model pembelajaran konvensional pada kelas kontrol. Penelitian dilakukan untuk melihat pengaruh model pembelajaran kooperatif tipe Numbered Head Together (NHT) dengan media kotak matriks terhadap kemampuan pemahaman konsep matematika siswa kelas XI IPA SMA Negeri 1 Selesai.

Desain penelitian yang digunakan pada penelitian ini adalah Pretest-Posttest Control Group Design. Variabel bebas dalam penelitian ini adalah model pembelajaran kooperatif tipe Numbered Head Together (NHT). Variabel terikat dalam penelitian ini adalah kemampuan pemahaman konsep matematika siswa. Tes yang digunakan dalam penelitian ini adalah tes subjektif yang berbentuk essay sebanyak 4 butir soal. Teknik analisis data yang digunakan adalah uji sistematik.

\section{HASIL PENELITIAN DAN PEMBAHASAN}

\section{A. Deskripsi Data}

Penelitian mengenai kemampuan pemahaman konsep matematika siswa ini dilakukan di SMA Negeri 1 Selesai. Populasi dalam penelitian ini adalah seluruh siswa kelas XI IPA SMA Negeri 1 Selesai yang terdiri dari empat kelas. Setelah peneliti menentukan populasi, langkah selanjutnya yaitu pemilihan sampel dengan menggunakan teknik Simple Random Sampling (acak). Dari proses acak terhadap empat kelas yang ada, diproleh sampel yaitu kelas XI IPA 3 yang berjumlah 32 siswa sebagai kelas eksperimen yang diajarkan dengan menggunakan model pembelajaran kooperatif tipe NHT (Numbered Head Together) dan kelas XI IPA 4 yang berjumlah 30 siswa sebagai kelas kontrol dengan model pembelajaran PBL tetapi dengan metode ekspositori. Metode ekspositori yang dimaksud adalah pembelajaran yang biasa diterapkan di SMA Negeri 1 Selesai, seperti model pembelajaran ceramah, diskusi kelompok, tanya jawab, dan penugasan.

Sebelum melakukan penelitian, peneliti terlebih dahulu membuat instrumen tes untuk mengukur kemampuan pemahaman konsep matematika siswa yang nantinya akan diberikan kepada kedua kelas. Instrumen tes ini terdiri dari empat soal uraian. Setelah melakukan instrumen, selanjutnya dilakukan uji validitas, uji reliabilitas, uji tarif kesukaran butir soal dan uji daya pembeda pada setiap butir soalnya. Berikut ini akan disajikan hasil pretest dan posttest pada kedua kelas tersebut yaitu kelas eksperiment dan kelas kontrol.

\section{Data Hasil Pretest Kemampuan Pemahaman Konsep Matematika Siswa Kelas Eksperimen Dan Kelas Kontrol}

Sebelum melaksanakan pembelajaran pada kedua kelas dengan model pembelajaran yang berbeda yakni dengan model pembelajaran kooperatif tipe NHT (Numbered Head Together) pada kelas eksperimen dan model pembelajaran PBL (Problem Besed Learning) tetapi dengan metode ekspositori terlebih dahulu diadakan pretest untuk mengetahui kemampuan awal siswa khususnya kemampuan pemahaman konsep matematika siswa dari kedua kelas tersebut. Data hasil pretest yang diberikan kepada kelas eksperimen berjumlah 
32 siswa dan kelas kontrol berjumlah 30 siswa. Untuk lebih jelasnya, data hasil tes kemampuan pemahaman konsep matematika siswa kelas eksperimen dan kelas kontrol disajikan dalam tabel statistik deskriptif berikut:

Tabel 1. Statistik Deskriptif Pretest Kelas Eksperimen Dan Kelas Kontrol

\begin{tabular}{cccc}
\hline & & \multicolumn{2}{c}{ Pretest } \\
\cline { 3 - 4 } No & $\begin{array}{c}\text { Ukuran } \\
\text { Statistik }\end{array}$ & $\begin{array}{c}\text { Kelas } \\
\text { Eksperime } \\
\text { nt }\end{array}$ & $\begin{array}{c}\text { Kelas } \\
\text { Kontrol }\end{array}$ \\
\hline 1 & Jumlah siswa & 32 & 30 \\
\hline 2 & Jumlah nilai & 915,4 & 956,3 \\
\hline 3 & Nilai maksimum & 66,6 & 66,6 \\
\hline 4 & Nilai minimum & 8,3 & 8,3 \\
\hline 5 & Rata-rata & 28.60 & 31,87 \\
\hline 6 & Simpangan baku & 16,92 & 17,67 \\
\hline 7 & Varians & 286,61 & 312,49 \\
\hline
\end{tabular}

Pada tabel di atas terlihat bahwa hasil perhitungan pretest pada kelas eksperimen diperoleh nilai varians 286,61 dan simpangan baku 16,92. Sedangkan pada kelas kontrol diperoleh nilai varians 312,49 dan simpangan bakunya yaitu 17,67. Hasil pemberian pretest diperoleh nilai rata-rata dikelas eksperimen 28,60 dan hasil pemberian nilai pretest pada kelas kontrol diperoleh nilai rata-rata 31,87. Perbedaan nilai rata-rata siswa antara kelas eksperimen dengan kelas kontrol menunjukkan homogen yang berarti kemampuan awal siswa sama. Hal ini juga dibuktikan dengan uji t pada lampiran 35 yaitu diperoleh $t_{\text {hitung }}=-0,743$ dan $t_{\text {tabel }}=1,671$. Karena $\mathrm{t}_{\text {hitung }}<\mathrm{t}_{\text {tabel }}$ yaitu $-0,743<1,671$ maka $\mathrm{H}_{\mathrm{o}}$ diterima dan $\mathrm{H}_{\mathrm{a}}$ ditolak maka disimpulkan tidak terdapat perbedaan kemampuan awal antara siswa kelas eksperimen dengan kelas kontrol.

Secara visual penyebaran data kemampuan pemahaman konsep matematika siswa kelas eksperimen yang menggunakan model pembelajaran NHT (Numbered Head Together) dengan media kotak matriks dan kelas kontrol yang menggunakan model PBL (Problem Besed Learning) tetapi dengan metode pembelajaran konvensional dapat dilihat pada histogram perbedaan nilai rata- rata, simpangan baku, dan varians pretest kelas eksperimen dan kelas kontrol sebagai berikut:

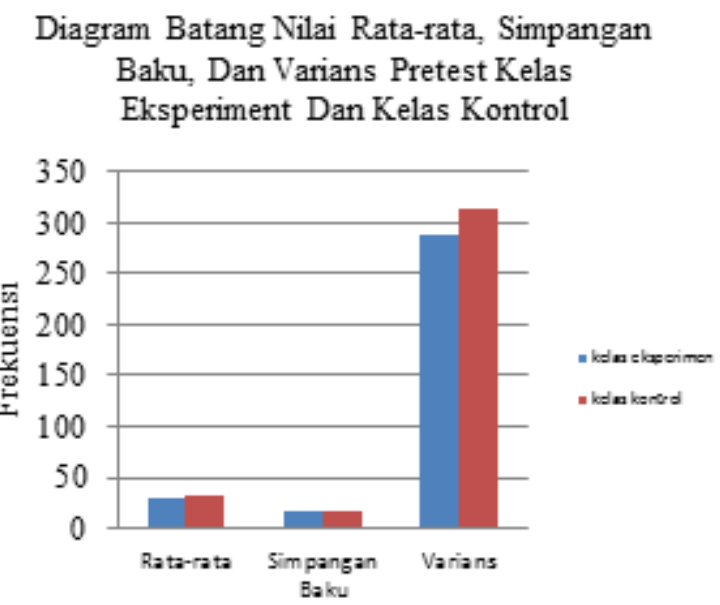

Gambar 3. Perbedaan Rata-Rata, Simpang Baku, Dan Varians Pretest Eksperiment Dan Kelas Kontrol

\section{Data Posttest Kemampuan Pemahaman Konsep Matematika Siswa Kelas Eksperimen Dan Kelas Kontrol}

Setelah diberikan pretest pada kedua kelas dan diperoleh tidak ada perbedaan kemampuan awal siswa, maka dilakukan pembelajaran yang berbeda yaitu di kelas eksperimen dengan model pembelajaran NHT (Numbered Head Together) dan di kelas kontrol dengan model pembelajaran PBL (Problem Besed Learning) tetapi dengan metode pembelajaran konvensional. Untuk lebih jelasnya, data hasil tes kemampuan pemahaman konsep matematika siswa kelas eksperimen dan kelas kontrol disajikan dalam tabel statistik deskriptif berikut:

Tabel 2. Statistik Deskriptif Posttest Kelas Eksperimen Dan Kelas Kontrol

\begin{tabular}{clcc}
\hline \multirow{2}{*}{ No } & Ukuran Statistik & \multicolumn{2}{c}{ Posttest } \\
\cline { 3 - 4 } & $\begin{array}{c}\text { Kelas } \\
\text { Eksperi } \\
\text { ment }\end{array}$ & $\begin{array}{c}\text { Kelas } \\
\text { Kontr } \\
\text { ol }\end{array}$ \\
\hline 1 & Jumlah siswa & 32 & 30 \\
\hline 2 & Jumlah nilai & 2356,4 & 1507 \\
\hline 3 & Nilai maksimum & 100 & 75 \\
\hline 4 & Nilai minimum & 33,3 & 16,6 \\
\hline 5 & Rata-rata & 73,63 & 50,23 \\
\hline 6 & Simpangan baku & 17,81 & 19,54 \\
\hline 7 & Varians & 317,54 & 382,03 \\
\hline
\end{tabular}


Pada tabel di atas terlihat bahwa hasil perhitungan Posttest pada kelas eksperimen diperoleh nilai varians 317,54 dan simpangan bakunya yaitu 17,81 . Sedangkan pada kelas kontrol diperoleh nilai varians 382,03 dan simpangan bakunya yaitu 19,54. Hasil pemberian Posttest diperoleh nilai rata-rata dikelas eksperimen 73,63 dan hasil pemberian Posttest diperoleh nilai rata-rata 50,23. Perbedaan nilai rata-rata siswa antara kelas eksperimen dengan kelas kontrol menunjukkan homogen yang berarti kekampuan awal sama. Hal ini juga dibuktikan dengan uji $t$ dalam lampiran 35 yaitu diperoleh $t_{\text {hitung }}=4,944$ dan $t_{\text {tabel }}=1,671$. Karena $t_{\text {hitung }}>t_{\text {tabel }}$ yaitu 4,944 > 1,671 maka $\mathrm{H}_{\mathrm{o}}$ ditolak dan $\mathrm{H}_{\mathrm{a}}$ diterima maka disimpulkan terdapat perbedaan kemampuan antara siswa kelas eksperimen dengan kelas kontrol setelah diberikan perlakuan. Secara visual penyebaran data kemampuan pemahaman konsep matematika siswa kelas eksperimen yang menggunakan model pembelajaran NHT (Numbered Head Together) dengan media kotak matriks dan model pembelajaran PBL (Problem Besed Learning) tetapi dengan metode pembelajaran konvensional di kelas kontrol dapat dilihat pada histogram perbedaan nilai rata-rata, simpangan baku, dan varians posttest kelas eksperimen dan kelas kontrol sebagai berikut.

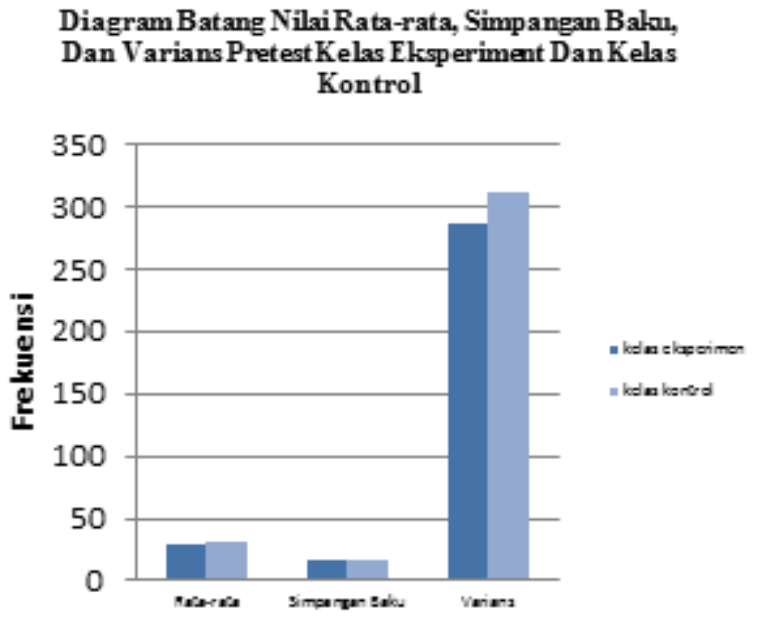

Gambar 4. Perbedaan Rata-Rata, Simpang Baku, Dan Varians Pretest Eksperiment Dan Kelas Kontrol

\section{Analisis Data}

Berdasarkan persyaratan analisis, maka sebelum dilakukan pengujian hipotesis, terlebih dahulu dilakukan uji prasyarat analisis terlebih dahulu terhadap data hasil penelitian. Uji prasyarat yang perlu dipenuhio yaitu berupa iji normalitas dan uji homogenitas. Hasil uji prasyarat analisis hingga pengujian hipotesis akan dipaparkan sebagai berikut:

\section{a. Uji Normalitas}

Uji normalitas yang digunakan adalah uji Liliefors. Uji Liliefors digunakan untukmengetahui apakah data berasal dari populasi yang berdistribusi normal atau tidak, dengan ketentuan bahwa data berasal dari populasi yang berdistribusi normal jika memenuhi kriteria $\mathrm{L}_{\mathrm{o}}<\mathrm{L}_{\mathrm{t}}$ diukur pada taraf signifikasi dan tingkat kepercayaan tertentu. Hipotesis yang diajukan dan akan diuji dalam uji normalitas ini sebagai berikut:

$\mathrm{H}_{\mathrm{o}}$ : data sampel berasal dari populasi yang berdistribusi normal

$\mathrm{H}_{\mathrm{a}}$ : data sampel berasal dari populasi yang tidak berdistribusi normal

Berdasarkan hasil perhitungan uji normalitas pretest dapat dilihat pada tabel dibawah ini:

Tabel 3. Rekapitulasi hasil perhitungan uji normalitas pretest - posttest dengan uji liliefors

\begin{tabular}{|c|c|c|c|c|c|}
\hline $\begin{array}{c}\text { D } \\
\text { at } \\
\text { a }\end{array}$ & kelompok & $\mathbf{L}_{\mathbf{o}}$ & $\mathbf{L}_{\mathbf{t}}$ & $\begin{array}{l}\text { kesimp } \\
\text { ulan }\end{array}$ & $\begin{array}{c}\text { keterang } \\
\text { an }\end{array}$ \\
\hline \multirow{2}{*}{ 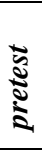 } & Eksperimen & $\begin{array}{c}0, \\
1463 \\
\end{array}$ & 0,1566 & $\begin{array}{c}\text { Terima } \\
\mathrm{H}_{\mathrm{o}}\end{array}$ & Normal \\
\hline & Kontrol & 0,1403 & 0,161 & $\begin{array}{c}\text { Terima } \\
\mathrm{H}_{\mathrm{o}}\end{array}$ & Normal \\
\hline \multirow{2}{*}{ 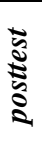 } & Eksperimen & 0,1127 & 0.1566 & $\begin{array}{c}\text { Terima } \\
\mathrm{H}_{\mathrm{o}}\end{array}$ & Normal \\
\hline & Kontrol & 0,1130 & 0,161 & $\begin{array}{c}\text { Terima } \\
\mathrm{H}_{\mathrm{o}}\end{array}$ & Normal \\
\hline
\end{tabular}

Berdasarkan tabel di atas, dapat dilihat bahwa data pretest dan posttest yang ada di kelas eksperimen dan kelas kontrol semuanya berdistribusi normal dengan $\mathrm{L}_{\text {tabel }}$ kelas eksperimen yaitu 0,1566 dan kelas kontrol yaitu 0,161 .

\section{b. Uji Homogenitas}


Uji homogenitas atau uji kesamaan dua varians populasi dilakukan dengan uji fisher. Untuk kriteria pengujian data kedua sampel adalah homogen jika $F_{\text {hitung }}<\mathrm{F}_{\text {tabel }}$ pada taraf signifikan 5\%. Rekapitulasi hasil perhitungan uji homogenitas dapat dilihat pada tabel dibawah ini.

Tabel 4. Rekapitulasi hasil perhitungan uji homogenitas pretest - posttest dengan uji Fisher

\begin{tabular}{|c|c|c|c|c|}
\hline Data & Kelompok & $\mathbf{F}_{\text {hitung }}$ & $\mathbf{F}_{\text {tabel }}$ & kesimpulan \\
\hline \multirow{2}{*}{$\begin{array}{l}\overline{\mathrm{s}} \\
\mathbf{0} \\
\vdots \\
\vdots\end{array}$} & Eksperimen & \multirow[b]{2}{*}{1,09} & \multirow[b]{2}{*}{1,84} & \multirow[b]{2}{*}{ Homogen } \\
\hline & Kontrol & & & \\
\hline \multirow{2}{*}{ 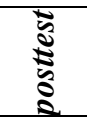 } & Eksperimen & \multirow[b]{2}{*}{1,20} & \multirow[b]{2}{*}{1,84} & \multirow[b]{2}{*}{ Homogen } \\
\hline & Kontrol & & & \\
\hline
\end{tabular}

Berdasarkan tabel di atas, didapat $\mathrm{F}_{\text {tabel }}$ $=1,84$ itu berarti $F_{\text {hitung }}$ lebih kecil dari $F_{\text {tabel }}$, sehingga dengan demikian diperoleh keputusan uji bahwa $\mathrm{H}_{\mathrm{o}}$ diterima, hal ini menunjukkan bahwa pemahaman konsep matematika siswa berasal dari populasi yang homogen.

\section{c. Uji kesamaan rata-rata}

Adapun hasil perhitungan kesamaan rata-rata antara kelas eksperimen dan kelas kontrol dapat dilihat pada tabel berikut :

Tabel 5. Hasil Perhitungan Kesamaan RataRata Kelas Eksperimen Dan Kelas Kontrol

\begin{tabular}{|c|c|c|c|c|}
\hline $\begin{array}{l}\text { Sumber } \\
\text { varians }\end{array}$ & $\begin{array}{c}\text { Kelompok } \\
\text { eksperimen }\end{array}$ & $\begin{array}{c}\text { Kelompok } \\
\text { kontrol }\end{array}$ & $S_{\text {gab }}$ & $\mathbf{t}_{\text {hitung }}$ \\
\hline $\mathbf{N}$ & 32 & 30 & \multirow{4}{*}{17,30} & \multirow{4}{*}{$-0,743$} \\
\hline $\bar{X}$ & 28,60 & 31,87 & & \\
\hline $\begin{array}{c}\text { Varians }( \\
\left.\mathrm{S}^{2}\right)\end{array}$ & 286,61 & 312,49 & & \\
\hline $\begin{array}{c}\text { Standar } \\
\text { Deviasi } \\
(\mathrm{S})\end{array}$ & 16,92 & 17,67 & & \\
\hline
\end{tabular}

Berdasarkan tabel di atas, dapat diambil kesimpulan bahwa dengan taraf singniatif $\propto=0,05, d b=\eta_{1}+\eta_{2}$ maka $d b=32+$ $30-2=60$, didapat $t_{\text {tabel }}=1,671$. Karena $t_{\text {hitung }}<$ $\mathrm{t}_{\text {tabel }}(-0,743<1,671)$, maka dapat disimpulkan bahwa terdapat kesamaan rata-rata antara kelas eksperimen dan kelas kontrol dengan demikian kedua yang akan digunakan sebagai sampel penelitian mempunyai kemampuan yang sama, olek karenanya kedua kelas dapat digunakan sebagai sampel penelitian.

\section{d. Pengujian hipotesis}

Telah diketahui bahwa kedua kelompok data pemahaman konsep matematika siswa adalah berdistribusi normal dan mempunyai varians yang homogen. Dari hasil perhitungan pada lampiran 35, diperoleh $t_{\text {hitung }}=4,944$. Pada $\mathrm{dk}$ $=60$ dan taraf nyata $\mathrm{a}=0,05$ diperoleh $\mathrm{t}_{\text {tabel }}=$ 1,671 , sehingga terlihat jelas bahwa $t_{\text {hitung }}>t_{\text {tabel }}$ yaitu 4,944>1,671. Berdasarkan pengujian hipotesis $\mathrm{H}_{\mathrm{o}}$ ditolak dan $\mathrm{H}_{\mathrm{a}}$ Diterima. Dengan demikian terdapat pengaruh model pembelajaran kooperatif tipe Numbered Head Together (NHT) dengan media kotak matriks terhadap kemampuan pemahaman konsep matematika kelas XI IPA SMA Negeri 1 Selesai Tahun Pelajaran 2019/2020.

\section{B. Pembahasan hasil penelitian}

Dalam penelitian ini peneliti mengguanakan pembelajaran Numbered Head Together (NHT) yang melalui beberapa tahap seperti: (1) peserta didik dibagi dalam kelompok, setiap peserta didik dalam setiap kelompok mendapati nomor. (2) Guru memeberikan tugas dan masing- masing kelompok mengerjakanya. (3) kelompok mendiskusikan jawaban yang benar dan memastikan tiap anggota kelompok dapat mengerjakanya/mengetahui jawabanya. (4) Guru memanggil salah satu nomor peserta didik dan peserta didik yang nomornya dipanggil melaporkan hasil kerjasama diskusi kelompoknya. (5) peserta yang dipanggil nomornya yang bersama kelompoknya akan mengerjakan kotak matriks dengan mencari potongan kotak matriks dan menyusunya di kotak matriks. (6) tanggapan dari teman lain, kemudian guru menujuk nomor yang lain dan seterusnya. (6) Guru menetapkan kelompok terbaik sampai kelompok yang kurang baik berdasarkan hasil LAS yang dikerjakan bersama kelompoknya. (7) kesimpulan. 
Proses pembelajaran selanjutnya kelas eksperimen mendapat perlakuan model pembelajaran Numbered Head Together (NHT) dengan media kotak matriks dan untuk kelas kontrol dengan Problem Based Learning (PBL) tetapi dengan metode pembelajaran konvensional seperti metode ceramah. Setelah proses pembelajaran berakhir, kelas eksperimen dan kelas kontrol diberi Posttest yang sama, yaitu 4 item soal uraian.

Berdasarkan hasil tes yang telah dilakukan diperoleh nilai rata-rata kelas eksperimen ( XI IPA 3) adalah 73,63 dengan simpangan baku adalah 17,81. Sementara nilai rata-rata kelas kontrol (XI IPA 4) 50,23 dengan simpangan baku adalah 19,54. Sehingga dari analisis data akhir (pretest) kelas eksperimen diperoleh $L_{0}=0,02888$ sedangkan $L_{t}=0,1566$. Ini menunjukkan bahwa diperoleh $L_{0}<L_{t}$ Pada uji normalitas, sementara itu analisis data akhir (posttest) kelas kontrol diperoleh $L_{0}=0,058$ sedangkan $L_{t}=0,161$ ini menunjukkan bahwa $L_{0}<L_{t}$ pada uji normalitas. Uji homogenitas juga menunjukkan hasil yang sama seperti uji normalitas. Jadi kesimpulanya adalah kedua kelas berasal dari kondisi yang sama.

Berdasarakan uji t-test diperoleh $t_{\text {tabel }}$ $=1,671$, sementara berdasarkan perhitungan yang telah dilakukan diperoleh $t_{\text {hitung }}=4,944$. Dari perhitungan terlihat bahwa $t_{\text {tabel }}>$ $t_{\text {hitung }}(4,944>1,671)$ maka hipotesis yang diajukan diterima. Dengan demikian, maka hasilnya dapat dikemukakan bahwa : “ Terdapat pengaruh model pembelajaran Numbered Head Together (NHT) terhadap kemampuan pemahaman konsep matematika siswa pada pokok bahasan matriks kelas XI SMA Negeri 1 Selesai tahun pelajaran 2019/2020”.

Berdasarkan hasil penelitian diperoleh bahwa Model pembelajaran Numbered Head Together (NHT) Berpengaruh Terhadap Kemampuan Pemahaman Konsep Matematika Siswa. Hal ini sesuai dengan penelitian terdahulu yang pernah dilakukan oleh penelitian lain, seperti penelitian yang dilakukan oleh Eka Rahma Wati dan Yesi Gusmania yang berjudul "Pengaruh Model Pembelajaran Kooperatif Tipe Numbered Head
Together (NHT) Terhadap Kemampuan Pemahaman Konsep Matematika Siswa Kelas VIII SMP Negeri 53 Batam", memperoleh hasil bahwa model pembelajaran NHT lebih baik dari model pembelaajaran konvensional (Eka Rahmawati dan Yessi Gusmania, 2017). Keberhasilan model NHT terhadap meningkatnya kemampuan pemahaman konsep siswa disebabkan karena dalam pembelajaran ini siswa bekerja sama dalam kelompok untuk menemukan masalah pada soal LAS yang diberikan oleh guru sehingga siswa dan guru saling melakukan interaksi berupa tanya jawab apa yang kurang dipahami oleh siswa. Pelaksanaan pembelajaran pada kelas eksperimen dan kelas kontrol masing-masing membutuhkan 3 kali pertemuan.

Berdasarkan uraian di atas dapat diakatakan bahwa "Terdapat pengaruh pendekatan kooperatif tipe (NHT) Numbered Head Together Dengan Media Kotak Matriks terhadap kemampuan pemahaman konsep matematika siswa di kelas XI SMA Negeri 1 Selesai".

\section{Keterbatas penelitian}

Penulis menyadari bahwa penelitian ini belum sempurna. Berbagai upaya telah dilakukan untuk mendapatkan hasil yang optimal. Oleh karena itu, masih ada beberapa faktor yang sulit dikendalikan sehingga penelitian ini memiliki keterbatasan diantaranya:

1. Kondisi awal yang merasa tegang dan mengalami kesulitan dalam beradaptasi pada awal proses pembelajaran dengan menggunakan model pembelajaran dengan menggunakan model pembelajaran NHT.

2. Pembelajaran dengan model pembelajaran NHT memerlukkan waktu yang cukup banyak, sedangkan waktu yang diberikan sangat terbatas sehingga managemen waktu yang tepat sangatlah penting penting dalam melakukan strategi.

3. Penelitian ini hanya dilakukan pada materi pelajaran matematika khususnya pada materi matriks, sehingga belum dapat dilihat hasilnya pada materi matematika lainnya. 


\section{IV.KESIMPULAN DAN SARAN}

\section{A. Kesimpulan}

Berdasarkan analisis data dan pembahasan maka dapat disimpulkan bahwa model pembelajaran Numbered Head Together (NHT) dengan media kotak matriks dapat memberikan pengaruh terhadap kemampuan pemahaman konsep matematika siswa yang lebih tinggi pada pokok bahasan matriks di kelas XI SMA Negeri 1 Selesai.

\section{B. Saran}

Berdasarkan kesimpulan diatas dan pengalaman dalam proses belajar mengajar yang terjadi selama penelitian, maka penulisan dapat memberikan saran-saran sebagai berikut :

1. Untuk guru model pembelajaran Numbered Head Together (NHT) dengan media kotak matriks menjadi salah satu model dan media pembelajaran yang dapat diterapkan dalam proses mengajar.

2. Untuk peneliti selanjutnya penelitian ini hanya fokus pada pokok bahasan matriks oleh karenanya untuk dapat dikembangkan pada pokok bahasan lainnya.

3. Dengan adanya beberapa keterbatasan dalam melaksanakan penelitian ini, maka sebaiknya dilakukan penelitian lebih lanjut yang meneliti tentang penerapan model pembelajaran Numbered Head Together (NHT) dengan media kotak matriks pada pokok bahasan lain untuk mengukur aspek lain.

\section{DAFTAR PUSTAKA}

Harleni, Silvia. Pengaruh Pendekatan Matematika Realistik (PMR) Terhadap Kemampuan Pemecahan Masalah Matematika Siswa Kelas VIII MTs Al Azhar Bulu Cina tahun Pelajaran 2017/2018. Jurnal Serunai Matematika. Vol.11, no (2), 2019.

Harleni, Silvia dan Ningtias, Ayin. Pengaruh Model Pembelajaran Konstektual Terhadap Pemahaman Konsep
Matematis Pada Siswa Kelas VIII SMP Swasta Budi Utomo Binjai Tahun Pelajaran 2018/2019. Jurnal Serunai Ilmu Pendidikan . Vol.5, no (1), 2019.

Harleni, Silvia dan Susilawati, Enny. Efektifitas Penggunaan Model Problem Based Learning Terhadap Kemampuan Pemecahan Program Linear Dengan Memamfaatkan Software QM Pada Mahasiswa STKIP Budidaya Binjai.

Herawati, Oktiana D. P. Pengaruh Pembelajaran Problem Posing Terhadap Kemampuan Pemahaman Konsep Matematika Siswa Kelas XI IPA SMA $N 9$ Palembang. Jurnal Pendidikan Matematika. Vol.4, no (1), 2010.

Istarani. 58 Model Pembelajaran Inovatif . Medan: Media Persada,2011.

Kunandar. Guru Profesional, Jakarta: Raja Grafindo Persada,2007.

Mudyahardjo. Pengantar Pendidikan: Sebuah Studi Awalnya Tentang Dasar-Dasar Pendidikan Pada Umumnya Dan Pendidikan Di Indonesia. Jakarta: Rajagrafindo Persada, 2001.

Mullis. TIMSS International Results In Mathematics. Amsterdam , The Netherlands: The International Associaton For The Educational Achievement(IEA), 2011.

Sagala. Konsep Dan Makna Pembelajaran, Bandung:Alfabeta, 2013.

Shoimin. 68 Model Pembelajaran Inovatif Dalam Kurikulum 2013. Yogyakarta: Ar-Ruzz Media, 2016.

Slameto. Belajar \& Faktor-Faktor Yang Mempengaruhi, Jakarta: Rineka Cipta, 2010. 